NBER WORKING PAPER SERIES

\title{
FOOD INSECURITY OR POVERTY? \\ MEASURING NEED-RELATED DIETARY ADEQUACY
}

\author{
Jayanta Bhattacharya \\ Janet Currie \\ Steven Haider \\ Working Paper 9003 \\ http://www.nber.org/papers/w9003 \\ NATIONAL BUREAU OF ECONOMIC RESEARCH \\ 1050 Massachusetts Avenue \\ Cambridge, MA 02138 \\ June 2002
}

Bhattacharya and Haider gratefully acknowledge the financial support from the USDA/Institute for Research on Poverty Small Grants Program. The authors thank Alison Jacknowitz for superb research assistance and are grateful for the helpful comments from the participants at the USDA Small Grants Workshop in Madison, Wisconsin; the USDA Small Grants Conference in Washington, DC; the Dartmouth Labor Seminar; and the University of Maryland Demography of Inequality Seminar. The views expressed herein are those of the authors and not necessarily those of the National Bureau of Economic Research.

(C) 2002 by Jayanta Bhattacharya, Janet Currie and Steven Haider. All rights reserved. Short sections of text, not to exceed two paragraphs, may be quoted without explicit permission provided that full credit, including (C) notice, is given to the source. 
Food Insecurity or Poverty? Measuring Need-Related Dietary Adequacy

Jayanta Bhattacharya, Janet Currie and Steven Haider

NBER Working Paper No. 9003

June 2002

JEL No. I32, I12

\begin{abstract}
We examine the extent to which food insecurity questions and the standard poverty measure are correlated with various dietary and physiologic outcomes. Our findings suggest that the correlations vary tremendously by age. We find that the food insecurity questions are correlated with the dietary outcomes of older household members, but that they are not consistently related to the diets of children. In contrast, poverty predicts dietary outcomes among preschoolers. Among adults, both poverty and food insecurity questions are good predictors of many dietary outcomes.
\end{abstract}

Jayanta Bhattacharya

Stanford University School of Medicine

Center for Primary Care Outcomes Research

Center for Health Policy

218 Encina Commons

Stanford, CA 94305-6019

jay@stanford.edu

Janet Currie

UCLA

405 Hilgard Avenue

Los Angeles, CA 90095-1477

and NBER

currie@simba.sscnet.ucla.edu
Steven Haider

RAND

1700 Main Street

Santa Monica, CA 90401

sjhaider@rand.org 


\section{Food Insecurity or Poverty? Measuring Need-Related Dietary Adequacy}

\section{INTRODUCTION}

In the 1990s, the United States Department of Agriculture (USDA) developed a battery of survey questions to measure need-related food sufficiency in the United States. The USDA convened expert panels on food insecurity and hunger measurement to develop a survey questionnaire, statistical measurement methods, food insecurity and hunger measures, and prevalence estimates for the nation. This instrument has been administered annually since 1995 as part of the Current Population Survey (CPS), and it has been adopted (in part) by many other surveys. ${ }^{1}$ Moreover, numerous papers have used these questions to analyze a variety of topics, with papers published in top journals such as the American Journal of Public Health and the Journal of the American Medical Association (see Bickel, et al, 2000, for a detailed bibliography). The clear benefit of these questions is that they are relatively inexpensive to ask and are intended to elicit direct information about dietary adequacy.

Several studies have begun the process of examining the validity of the food insecurity questions. These studies have examined how the questions are correlated among themselves (i.e., their internal validity) and how the questions are correlated with demographic characteristics, household characteristics, and dietary outcomes (i.e., their external validity). ${ }^{2}$ Generally, these studies find that food insecurity questions are correlated in expected ways with both internal and external factors. For example, relying on the Continuing Survey of Food Intake by Individuals, Rose (1999) found that, in households reporting insufficient food, most household members took in significantly less of most vitamins and

\footnotetext{
${ }^{1}$ For example, some of the food security questions are included in the Panel Study of Income Dynamics, the Survey of Program Dynamics, the Health and Retirement Surveys, the NHANES III (which we use here), the Los Angeles Family and Neighborhood Survey, and welfare attrition studies in Michigan and California.
} 
minerals than did member of other households. One exception was that preschoolers in food-insecure households did not suffer from low consumption.

A significant drawback of the previous validation studies is that they did not use an alternative indicator of low consumption as a benchmark for assessing the quality of the food insecurity questions. One benchmark measure is the standard poverty measure. The intent of the poverty measure is to identify households with "inadequate resources to obtain basic living needs," where basic needs are considered to be food, clothing, and shelter (see Citro and Michael, 1995). The U.S. government has been producing official poverty estimates for over 30 years. Current poverty statistics in the United States are calculated by comparing a family's actual income to a poverty line that was originally calculated to represent the income needed for adequate consumption (Orshansky, 1965). Using the poverty measure could be considered a fairly weak means of comparison, given the widespread criticism of the official poverty measure (Citro and Michael, 1995). For example, the official method of measuring poverty ignores inkind governmental transfers (such as food stamps, housing, and medical assistance), the costs of earning wage income (such as child care expenses), and regional differences in the cost of living. ${ }^{3}$

In this paper, we assess the empirical content of the food insecurity questions, advancing the literature in several directions. First, we do not simply examine whether the food insecurity questions are correlated with other factors, but rather we focus on how well they are correlated. The standard poverty measure serves as a useful benchmark for these purposes because it has been used extensively and can be computed from many different data sets. Second, this paper uses a unique dataset, the National Health and Nutrition Examination Survey III (NHANES III). In addition to the dietary recall information collected in other data sets, NHANES III collects and analyzes blood from its participants. Thus, we are able to

\footnotetext{
${ }^{2}$ For a useful discussion of these studies, see the 1999 Supplement "Symposium: Advances in Measuring Food Insecurity and Hunger in the U.S." to the Journal of Nutrition. Other validation studies include Derrickson et al. (2000), Hamilton et al. (1997), and Rose and Oliveria (1997).

${ }^{3}$ In earlier drafts of this paper, we constructed alternative poverty measures based on some of the suggestions in Citro and Michael (1995). However, not all of these suggestions can be implemented given the data in NHANES III, and the correlation between the alternative measures and the official poverty measure is very high. Thus, we do not consider additional measures in this paper.
} 
examine measures of diet adequacy that can be collected without recall or proxy bias from individuals of all ages. Third, we are more precisely able to examine how the correlations between the measures and dietary outcomes vary by age. This last point is particularly valuable given that standard food insecurity questions make distinctions by age. For example, one distinction between the CPS's two most severe categories of food insecurity rests on whether children are skipping meals.

We find that the food insecurity questions are correlated with the dietary outcomes of older household members, but that they are not consistently related to the diets of children. In contrast, poverty predicts dietary outcomes among preschoolers. Among adults, both poverty and food insecurity questions are good predictors of many dietary outcomes. However, poverty may be a better overall predictor of diet quality in that it is more consistently related to a range of dietary outcomes than the food insecurity questions.

We note one important drawback of this paper from the outset. Most studies that examine food insecurity use a summary measure based on a series of questions. NHANES III does not contain the entire series of questions, so a direct examination of the summary measure cannot be undertaken. However, the questions that are available in NHANES III are very similar to those available in the CPS, and these questions are very highly correlated with the summary measures. Thus, we interpret our results to be a strong indicator of what would be obtained if the entire set of food insecurity questions were available in NHANES III.

The rest of the paper is organized as follows. We describe the data set in Section 2 and the construction of variables in Section 3; the Appendix gives significantly more details about variable construction. Section 4 provides a regression analysis of the relationship between the variables and dietary outcomes. We end with a discussion and conclusion in Section 5. 


\section{DATA}

We rely on data from the National Health and Nutrition Examination Survey III for our analysis. This national survey was conducted between October 1988 and October 1994 and included nearly 34,000 respondents, aged 2 months and older. The survey over-sampled blacks, Mexican Americans, younger children, and older persons to assure adequate representation and includes weights to make the sample nationally representative.

NHANES III collects information in usual survey domains, including demographics (e.g., age and gender), income (e.g., labor income and government program participation), self-reported health (e.g., diseases and functional status), and subjective food insecurity and hunger questions. In addition, the survey also collects substantial health information not normally found in surveys, including data from a physical exam conducted by a doctor, blood and urine tests, and a dietary intake model.

\section{VARIABLE CONSTRUCTION}

Our goal in this paper is to compare the extent to which the food insecurity measures and the standard poverty measure are correlated with poor consumption outcomes. In this section, we discuss the construction of the various measures that we examine. We summarize these measures in Table 1 and provide details of their construction in the Appendix.

\section{Food Insecurity and Poverty Measures}

The USDA developed an extensive battery of questions that are included in the CPS to examine food insecurity and hunger in the United States. Based on responses to these underlying questions, households are placed into one of the following four groups, in order of increasing food insecutiry: ${ }^{4}$

A. Food secure: Households show no or minimal evidence of food insecurity. al., 2000).

${ }^{4}$ These descriptions come from a USDA report, "Guide to Measuring Household Food Security" (Bickel et 
B. Food insecure without hunger: Food insecurity is evident in household members' concerns about adequacy of the household food supply and in adjustments to household food management, including reduced quality of food and increased unusual coping patterns. Little or no reduction in members' food intake is reported.

C. Food insecure with hunger (moderate): Food intake for adults in the household has been reduced to an extent that implies that adults have repeatedly experienced the physical sensation of hunger. In most (but not all) food-insecure households with children, such reductions are not observed at this stage for children.

D. Foods insecure with hunger (severe) - At this level, all households with children have reduced the children's food intake to an extent indicating that the children have experienced hunger. For some other households with children, this already has occurred at an earlier stage of severity. Adults in households with and without children have repeatedly experienced more extensive reductions in food intake.

Thus, the categories have an ordinal quality, with a clear ranking between high and low, and they are given an explicit definition of what is likely to be observed at the various levels. For example, only the last category tends to be associated with children experiencing inadequate consumption.

Although the complete CPS food security module is not included in NHANES III, a few very similar questions are included. These questions are asked of the family respondent about all family members and of individuals regarding themselves. Such individual-level questions are not asked in the CPS. Table A1 provides the text of the NHANES questions and the comparable CPS questions.

We construct five different measures of food insecurity based on these questions. These measures are summarized in Table 1. The first three measures (FSfam1 through FSfam3) are based on the answers of the family respondent to questions regarding the entire family, and the last two measures (FSself1 and FSself2) are based on individuals' responses about themselves. FSfam 2 and FSfam 3 were only asked in the second phase of the survey, thus they are only available for half of the sample. Few children under age 12 answer the self-reported questions, so we exclude children from our analysis of these questions. In the Appendix, we present tabulations from the CPS that suggest that the measure FSfam 1 corresponds to a concept that lies somewhere between categories B (food insecure without hunger) and C (food insecure with moderate hunger). The measure FSfam 2 corresponds closely to category $\mathrm{C}$ and FSfam 3 corresponds closely to category D (food insecure with severe hunger). This analysis is very similar to the ranking of questions provided in Hamilton et al. (1997). 
As a benchmark for the food insecurity questions, we also examine the extent to which poverty is correlated with low consumption. As mentioned previously, there is much dissatisfaction with the U.S. poverty measure, and many suggestions have been made to improve it so it can better identify lowresource households. ${ }^{5}$ Moreover, income in NHANES III is only collected through one survey question about total household income, making the poverty assessment in the NHANES even more problematic. Despite these drawbacks, the poverty measure still provides a useful alternative measure of potential low consumption to serve as a benchmark for the food insecurity questions.

\section{Consumption Measures}

NHANES III collects detailed dietary recall information for the previous day (midnight to midnight) and the 30 days prior to the interview. We rely on two summary measures of the 24-hour dietary recall information, both of which are provided on the public-use NHANES data files, since the 24hour recall data correspond most closely to what has previously been analyzed in validation studies.

The first measure is the USDA's Healthy Eating Index (HEI). The HEI provides a convenient way to summarize all the dietary recall data available in NHANES III in order to assess overall diet quality (Kennedy et al., 1995). The index is the constructed as the sum of ten underlying components, and each component is scored between 0 and 10 ; thus, the highest score possible is 100 . The main drawback of the HEI is that it does not penalize a diet that is high in empty carbohydrates from sweets.

The second measure is total caloric intake, which is computed by using detailed recipe information.

\section{Clinical Measures}

We rely on multiple measures based on the clinical information. The first two measures are based on the body mass index (BMI). BMI is defined as (weight in grams)/(height in meters) ${ }^{2}$. We determine

\footnotetext{
${ }^{5}$ See Citro and Michael (1995).
} 
whether individuals have low BMI or are obese. The cutoffs for low BMI and obesity differ by age and gender as shown in the Appendix. Note that whereas the discussion of food insecurity often focuses on insufficient consumption, obesity is an important and growing public health problem that disproportionately affects the poor.

The other two measures are based on micronutrients (serum vitamins and minerals) in the blood. The relationship between micronutrient intake and blood levels of these nutrients is complicated. Because the body can store some vitamins and minerals for long periods, it is not anomalous to find a respondent who has not recently consumed the recommended amount of some vitamin and yet is not deficient in that vitamin according to blood tests. Moreover, there are genetic components to certain deficiencies. Nevertheless, blood tests can provide solid, objective evidence of poor diets when properly interpreted.

We use multiple micronutrient measures. We first examine whether individuals are short of vitamins $\mathrm{A}, \mathrm{C}$, and $\mathrm{E}$ and folate separately. In addition, we also construct a summary measure for whether an individual is short of any of these micronutrients; we refer to this group as 'short vitamins.' The other measures include whether someone is anemic based on hemoglobin and hematocrit levels and whether a person has high cholesterol based on serum levels. All vitamin deficiencies are cause for concern, but anemia may be particularly pernicious since even slight deficiencies in iron are associated with impaired cognitive functioning, especially in children. Table A4 presents the cutoff values we use to determine vitamin and mineral deficiencies, anemia, and high cholesterol. These values are taken from a standard internal medicine textbook (Wilson et al., 1991).

\section{$\underline{\text { Sample Characteristics }}$}

In Tables $2 \mathrm{~A}$ and $2 \mathrm{~B}$, we present sample sizes and sample means for the various measures. Because some of the measures of interest were not asked in all versions of the survey, we use all the data 
available for any particular analysis. ${ }^{6}$ In the first row of the tables, we present the overall sample size for individuals in that age group.

The first group of variables includes the poverty rate and the five different measures of food insecurity. The poverty rate in NHANES III follows the general pattern found in other surveys, although the poverty rate for younger individuals is higher. For example, relying on the CPS, the 1991 poverty rate was 21.8 percent for individuals under 18 (Baugher and Lamison-White, 1996). NHANES III implies that $27.9,25.5$, and 22.2 percent of individuals aged $0-5,6-11$, and $12-17$ years old were poor. The CPS implies that the 1991 poverty rate was 11.4 percent for individuals 18-64, whereas the NHANES estimates imply that 9.8 percent of individuals $18-64$ without children were in poverty and 16.3 percent of individuals with children were in poverty. Finally, the CPS implies that 12.4 percent of individuals 65 and older were poor, and NHANES III implies that 11.6 percent were poor. One explanation for the higher prevalence of child poverty in NHANES III is that poor families were more likely to participate in the NHANES because it provided an opportunity for a detailed medical check-up.

We turn next to the food insecurity questions. Although it is difficult to compare the prevalence estimates to those reported from other sources given our reliance on specific questions, the levels and patterns appear to be reasonable except for one anomaly—namely, the frequency of positive responses to FSfaml (sometimes or often not enough food for the family) is low relative to the responses for the other questions. We do not have an explanation for this pattern. However, our estimates of the number of households that report yes to FSfam 2 and FSfam 3 are similar to those found by researchers using the CPS. We obtain 6.0 and 2.6 percent, respectively, while Andrews, Nord, Bickel, and Carlson (2000) report the analogous proportions in the CPS to be 6.5 and 2.0 percent.

${ }^{6}$ Specifically, four versions of the NHANES III questionnaire were used over the 6 years that the survey was fielded. Two of the food security questions (FSfam 2 and FSfam 3) were asked in only two versions of the survey. In addition, certain lab results were not reported for individuals of varying ages; this particularly affects the sample sizes for children 0 to 5 years old. 
Tables $2 \mathrm{~A}$ and $2 \mathrm{~B}$ also present descriptive statistics for the dietary outcomes of interest as well as other demographic information. These tables highlight striking variations in most of our nutritional outcome measures by age. For example, calorie consumption is high for very young children, falls for teens, rises again for prime-age adults, and then falls among the elderly. Similarly, anemia is most common among the very young, while high cholesterol is mainly an adult problem. These patterns highlight the importance of conducting separate analyses by age.

Finally, Tables $2 \mathrm{~A}$ and $2 \mathrm{~B}$ show some important demographic differences between the different groups we examine. For example, non-elderly adults in households with children are somewhat younger, more likely to be female, and less likely to be white than adults in households without children. Also, it is striking that elderly adults are much more likely to be white than are non-elderly adults. We will control for these differences in our regression models.

\section{THE EMPIRICAL CONTENT OF THE FOOD INSECURITY QUESTIONS}

To examine the relationship between the poverty and food insecurity questions and the dietary outcomes, we rely on a regression analysis. We first discuss the details of these methods and then present our results.

\section{$\underline{\text { Regression Methods }}$}

We examine the empirical content of the various poverty and food insecurity questions by means of regression analysis. To motivate the regression analysis, consider a simpler analysis in which we calculate the mean outcomes for various subgroups. For example, we could compute the mean rate of vitamin deficiencies for the entire population of adults and for the subpopulation for which the adult member reports that there is not enough food to eat (i.e., FSfaml equal to 1). To the extent that the mean is greater for the subpopulation than for the entire population, we would conclude that a particular variable has some predictive validity for vitamin deficiencies. 
There exists at least one significant problem with such a comparison. Specifically, the underlying physiologic process that translates food into vitamins and minerals in the blood varies with age and genetic factors that are associated with gender and race. Moreover, given that age, gender, and race are correlated with poverty, it is possible that any mean differences that we would report are resulting from differences in sample composition. For example, it is well known that blacks are poorer than whites in the United States and that blacks are more likely to be anemic, in part because they are more likely to carry the sickle-cell trait. Any differences in anemia between the general population and those in poverty could be due to differences in sample composition rather than differences in the adequacy of consumption.

To handle these composition issues, we rely on a regression analysis in which we regress different outcomes on the various food insecurity and poverty measures, controlling for the population composition. Formally, consider the model

$$
\text { Outcome }_{i}=\alpha+\text { Measure }_{i} \beta+X_{i} \gamma+\varepsilon_{i},
$$

where Measure $_{i}$ is a particular predictor of interest such as FSfam1, Outcome ${ }_{i}$ is a consumption or clinical outcome measure, and $X_{i}$ are other characteristics that describe the composition of the sample. The coefficient $\beta$ measures the difference in the outcome between the groups defined by the predictor Measure ${ }_{i}$

We estimate the regressions separately for the $0-5,6-11,12-17,18-64$, and $65+$ age groups. We also divide non-elderly adults into those who do and do not have children, in order to allow the correlation between the measures and the outcome variables to vary by subgroup. We include age, gender, and race to control for potential compositional differences related to physiologic processes, and we include urban residence and census region to control for potential compositional differences related to 
regional food prices and diets. ${ }^{7}$ All of the regressions are weighted using the NHANES III sample weights.

\section{$\underline{\text { Regression Results }}$}

The regression results are presented in Tables 3 through 8 . Each coefficient/standard error combination represents a separate regression. For example, Table 3 presents the results for 40 different regressions. We withhold the other coefficient estimates for the sake of brevity.

Examining the results for the $0-5$ age group in Table 3, we find that young children in poverty systematically have different dietary outcomes from young children not in poverty. Poor children have diets with lower HEI, higher caloric intake, higher BMI (more obesity and less low BMI), higher vitamin deficiencies, and higher rates of anemia. A useful way to interpret the magnitude of these coefficients is to compare the coefficients to the mean of the dependent variables. For example, controlling for the other demographic factors, the difference in vitamin deficiencies between the poor and non-poor is approximately 20 percent of the mean in the population of 0 - to 5-year-olds (a coefficient of 0.053 and a dependent variable mean of 0.247). Examining the results for the individual vitamins suggests that this result is driven by the correlation with vitamin A. Similarly, the difference in anemia between poor and non-poor children is 28 percent of the population mean (a coefficient of 0.045 and a dependent variable mean of 0.149$)$.

Turning to the food insecurity questions (FSfam1 through FSfam3) for the 0-5 age group, the results are much less decisive. Few of the coefficients are statistically significant at standard levels, and the signs of the coefficients are not the same across various measures. An important exception to this finding is that indicators for the questions about skipping meals (FSfam2 and FSfam3) are significant

\footnotetext{
${ }^{7}$ Specifically, we include a quadratic in age, a gender indicator, race indicators (Hispanic, black, and other), and a complete set of interactions between an urban indicator and census region indicators (Northeast, Midwest, West, and South) in most regressions. The exception to this description is the regressions for the 0 - to 5-year-olds: for this age group, we only include a linear term in age because some of the outcomes are not available for the youngest ages.
} 
predictors of low BMI. However, these food insecurity indicators do not predict any other dietary outcomes and are predicted to have the opposite effect on low BMI in models estimated using children 6 to 11 years old.

We examine the results for the 6-11 age group in Table 4 and find that the relationship between the dietary outcomes and food insecurity and poverty are all fairly weak. For example, the difference between a poor and non-poor 6- to 11-year-old is 16 percent of the dependent variable mean (a coefficient of 0.023 with an overall mean of 0.147 ), but the coefficient is not significantly different from 0 (a standard error of 0.017); however, poverty does predict vitamin A and C shortages. For other dietary outcomes, we find little difference between the children in poverty and the children not in poverty. The results for the food insecurity questions are mixed. One coefficient is rather large and significant: FSfam3 appears to be an important predictor of vitamin deficiency (the coefficient of 0.131 can be compared with a mean of 0.147$)$. However, this result is not observed with the other food insecurity questions or with the younger or older children.

The estimates for the 12-17 age group are shown in Table 5. Poverty is not a predictor of vitamin deficiencies or anemia but is predictive of obesity (the coefficient of 0.050 can be compared with a mean prevalence of 0.118 ) and high cholesterol (the coefficient of 0.053 can be compared with a mean prevalence of 0.093 ). Once again, the food insecurity questions appear to be unsystematic indicators of nutritional problems. A parent's affirmative response to the various food insecurity questions (FSfam1, FSfam2, or FSfam3) is significantly associated with the consumption of fewer calories by teens, but the self-reports (FSself1 and FSself2) are associated with significantly more calories. The coefficients on the food insecurity indicators in the regressions for other outcomes are either close to 0 or do not follow a systematic pattern.

Table 6 presents results for individuals aged 18 to 64 without children. These results indicate much stronger correlations between poverty, food insecurity, and dietary outcomes. The poor have a less healthy diet (low HEI), lower caloric intake, more obesity, and are more likely to be vitamin deficient. 
The difference in vitamin deficiency between poor and non-poor adults is 30 percent of the population mean (a coefficient of 0.078 with a mean deficiency of 0.255 ). Examining the underlying vitamin measures, this correlation is driven by the correlation with vitamin $\mathrm{C}$ whereas the correlation for 0 - to 5year-olds was driven by vitamin A.

The food insecurity questions are also correlated with nutritional outcomes for this group. The estimates indicate that individuals judged food insecure on the basis of the family food insecurity questions have a less healthy diet as measured by the HEI and are more likely to be vitamin deficient. The self-reported food insecurity questions are even more strongly correlated with inadequate consumption. In addition to having a less healthy diet and being prone to vitamin deficiencies, adults who self-report food insecurity have higher calorie diets, are more likely to be obese, and are more likely to be anemic. Overall, the family food insecurity questions have estimated effects similar to those of poverty, while the individual-level questions predict even larger differences in nutritional outcomes.

We present results for non-elderly adults with children in Table 7 . The estimates indicate that the poor have a lower HEI, more obesity, and higher rates of vitamin deficiency. For this population, the difference in vitamin deficiencies between poor and non-poor is almost 40 percent of the group mean (a coefficient of 0.117 versus a mean of the dependent variable of 0.306 ).

Very similar results are obtained using the food insecurity questions. For example, two of the family-reported food insecurity questions (FSfam1 and FSfam3) suggest that the food insecure eat a less healthy diet and are more likely to have a vitamin deficiency, with estimated effects similar to those obtained using the poverty measure. The other family food insecurity measure (FSfam 2 ) only indicates a difference in the prevalence of vitamin deficiencies between the secure and insecure, but the magnitude is half that of the other measures. The more severe self-reported measure (FSself2) suggests larger differences in dietary outcomes.

Finally, Table 8 presents the results for the elderly (aged 65+). The difference between the poor and non-poor elderly is quite striking. The poor have lower-quality diets (measured by HEI), eat fewer 
calories, suffer more from low BMI, are more likely to be vitamin deficient, and are more likely to be anemic. The relative differences between the poor and non-poor are also much stronger than for younger populations. For example, the difference in vitamin deficiencies between the poor and non-poor elderly is 63 percent of the population average (a coefficient of 0.084 versus a dependent variable mean of 0.133 ) and the difference in anemia is 50 percent (a coefficient of 0.042 versus a dependent variable mean of $0.089)$.

The differences between the food insecure and the food secure vary with the question asked. The general food insecurity question (FSfam 1 ) is more predictive than poverty of HEI, low calories, low BMI, and vitamin deficiencies, although it does not predict anemia. The skipping meals question (FSfam2) has little predictive power. The self-reported responses, on the other hand, distinguish between individuals with different dietary outcomes fairly well. Individuals who report skipping meals at least once eat a less healthy diet and have a much greater probability of having low BMI and of being short vitamins. The results are somewhat stronger if individuals skipped meals at least three times in the last 30 days (FSself2).

\section{CONCLUSION AND DISCUSSION}

Significant resources have been devoted to developing measures of food insecurity and hunger in the United States, and studies are beginning to examine how well these measures perform. In this study, we extend this literature in a several directions. First, we rely on detailed measures of dietary outcomes, including information from dietary recalls and blood analysis. Second, we examine how the correlations between food insecurity and outcomes differ across various age groups. Third, we compare the estimated effects of food insecurity indicators to those of another potential indicator of poor consumption, the standard poverty measure.

Our results lead to several conclusions. First, other researchers have found that the less severe measures of food insecurity were not correlated with poor diets for preschoolers. Similarly, we find little 
evidence that family reports of food insecurity are predictive of nutritional outcomes in the $0-5$ age group. It is especially striking that the measure incorporating questions about children skipping meals is not predictive of young children's nutritional outcomes. In contrast, poverty is a significant marker of differential consumption patterns. For example, children in poverty are significantly more likely to have some vitamin and mineral deficiencies (vitamin A and iron) and to have low BMI on average.

Among school-age children (6 to 17), we find few systematic differences in diet either between the poor and the non-poor or between the food secure and the food insecure. There are a few potential explanations for this pattern. First, it is possible that the nutritional outcomes of school-age children are not as closely tied to family resources as are the outcomes of younger children and adults. For example, these children might have the ability to supplement their consumption opportunities at schools, during extracurricular activities, at friends' and neighbors' homes, or through working. Another possibility is that the physiologic processes that translate consumption into dietary outcomes are much noisier for this group, making any differences more difficult to detect.

The results for adults 18 and older are much stronger for all of the measures. Among non-elderly adults (18 to 64 years old, with and without children), individuals in poverty have a less healthy diet and higher BMI, and are more likely to be vitamin deficient. Compared with children, the differences in vitamin deficiencies between poor and non-poor adults are relatively much greater. Family measures of food insecurity are also associated with vitamin deficiencies and less healthy diets among non-elderly adults, whether or not they have children. Self-reports of food insecurity are associated with more calories and more anemia, but only among adults without children.

The estimated effects of both poverty and food insecurity are strongest among the elderly. The elderly poor consume fewer calories, have a lower-quality diet, and are much more likely than the nonpoor to exhibit vitamin and mineral deficiencies. Moreover, among the elderly, reports of food insecurity generally yield very similar estimates. The only food insecurity measure that does not predict nutritional outcomes among the elderly is the one based on family reports of adults skipping and/or reducing meals. 
Overall, consistent with previous research, we find that the food insecurity questions are often correlated with dietary outcomes. However, we also find that the strength of the correlation varies tremendously by age and that the food insecurity questions often perform no better than standard poverty measures in predicting dietary outcomes. This comparison is particularly stark for the youngest age group. We find that even the food insecurity question that directly inquires about children skipping meals is not correlated with their dietary outcomes, but the poverty measure is. Given the dissatisfaction with the current poverty measure and the recent work to improve it, it is possible that an improved poverty measure could even dominate the food insecurity questions as a predictor of dietary outcomes.

Finally, although the focus of this research is related to measurement, it is important to note the substantive aspects of our findings. First, individuals in poverty tend to have different dietary outcomes even at the basic level of vitamin deficiencies and anemia. This finding is true for most age groups in the population, including two particularly vulnerable groups, the youngest and the oldest. This finding is important when considering the sufficiency of the social safety net in the United States.

Second, our findings suggest several underlying behavioral issues of interest. For example, poverty is associated with low caloric intake and low BMI for the elderly, but has the opposite relationship among the very young. These findings could be explained by models that consider quality/quantity and time/money trade-offs in food production. As another example, we find much variation by age in the relationship between poverty and dietary outcomes. Adult dietary outcomes are more correlated with poverty than child outcomes, and dietary outcomes of younger children are more correlated with poverty than are the dietary outcomes of older children. It is possible that parents protect their children from the effects of poverty to the extent that they can, and that older children have more opportunities to supplement their consumption outside the home. It would be tremendously useful to have a better understanding of these protective family behaviors. 


\begin{abstract}
APPENDIX
We first provide details on the construction of the various measures used in this paper. We then provide further details on the CPS analysis regarding how the specific questions correspond to the food security scale.

Details of the Variable Construction for NHANES III
\end{abstract}

We discuss the details for each type of variable and present sample sizes and means in $2 \mathrm{~A}$ and 2B. We consider non-response to be missing values, and thus the sample sizes vary tremendously. For our analysis, we use all available data unless we specify otherwise.

Food insecurity questions. We analyze the five food insecurity questions asked in NHANES III and Table A1. Questions HFF7 and HFF8 were only asked during two of four survey versions. We only used actual self-responses to questions DRPQ7 and DRPQ8, excluding proxy or joint proxy/selfresponses, for ages 12 and older.

Poverty measures. The income-to-poverty ratio is based on the official U.S. poverty definition and is computed by NHANES III. The underlying income information comes from one total income question, but the respondents are first prompted about the existence of many different sources of income (e.g., labor income and transfer income).

Consumption measures. We construct two measures of consumption based on 24-hour dietary recall data. The first is the Healthy Eating Index (HEI), which is a summary measure of the overall dietary quality. The underlying ten components are listed in Table A3; the HEI is computed by NHANES III. The second is the caloric content of the 24-hour dietary recall. The caloric content is determined by a recipe analysis of the 24-hour dietary recall, also provided by NHANES III.

Clinical measures. We construct three clinical measures of dietary outcomes. The first two are based on the body mass index (BMI), which is defined as (weight in grams)/(height in meters) ${ }^{2}$; the components for this calculation were obtained by clinical exam. The second two measures are based on 
the clinical analysis of blood draws. One is whether individuals are short of vitamins A, C, E, or folate, and the other is whether individuals are anemic. The cut-offs for each of these assessments are presented in Table A3. Although blood was potentially taken from individuals of all ages, vitamin A, C, and E levels were not reported for children under 4 and vitamin C levels were not reported for 4- and 5-yearolds; for this age group, we still analyze shortages in vitamins A and E.

\section{Details for the CPS Analysis}

To examine the relationship between the questions in the NHANES and the food security composite categories reported in the CPS, we directly compare the similar CPS questions (see Table A1) to the CPS composite categories using April 1999 CPS data. We examine the relationship by comparing cross-tabulations, computing the amount of agreement between the measures, and noting whether the disagreement is systematic. We present the results of these comparisons in Table A2.

Turning to the results, the first question (sometimes or often do not have enough to eat) is most closely related to category $\mathrm{C}$, as measured by the amount of agreement between the measures $(94.2$ percent). It is worth noting that much of the disagreement implies that many individuals who are not labeled as food insecure with moderate hunger still answered yes to the question, perhaps implying that the question is not sufficient to place someone in category C. Interestingly, the opposite conclusion is reached when examining the correspondence of the question with category $\mathrm{B}$, suggesting that the question measures a concept somewhere in between the two categories. The last two questions correspond much more closely to particular categories. The question regarding whether adults skip meals agrees most often with category C ( 97.8 percent), with the disagreement not being very systematic. The question regarding children skipping meals agrees most frequently with category D (99.5 percent), again with the disagreement not being very systematic. 
TABLE A1

Comparing Food Insecurity Questions in the NHANES and CPS

NHANES Questions

CPS Questions

Household Level Questions

HFF4. Do you have enough food to eat, sometimes

not enough to eat, or often not enough to eat?

SS1A. Which of the following statements best describes the amount of food eaten in your household - enough to eat, sometimes not enough to eat, or often not enough to eat?

HFF5. Thinking about the past month, how many days did (you/your family) have no food or money to buy food?

HFF7. Thinking about the past month, did

SHM2. Now think about the last 30 days. Did (you/adult members of your family) ever cut the size of your meals because there was not enough money or food? [yes/no] (you/adults in your household) ever cut the size of your meals or skip meals in the last 30 days because there wasn't enough food?

HFF8. Thinking about the past month, did you cut the size of your children's meals or did they skip meals because there was not enough money for food? [yes/no]

SSHM2/SSHM4. In the last 12 months, since October of last year, did you ever cut the size of (any of the children)" meals because there wasn't enough money for food? Did this ever happen in the last 30 days?

HRSF12M2. The composite food security scale computed by the CPS.

Individual-Level Questions

DRPQ7. During the past month did (you/_) skip any [no individual level questions available] meals because there wasn't enough food or money to buy food? [yes/no]

DRPQ8. How many days in the past month did (you/_) skip any meals because there wasn't enough food or money to buy food?

Note: CPS Question SS1A was asked of 4 of 8 of the April rotation groups. Questions SSHM2 and SSHM4 were asked of 7 of 8 rotation groups. 
TABLE A2

Benchmarking Individual CPS Questions

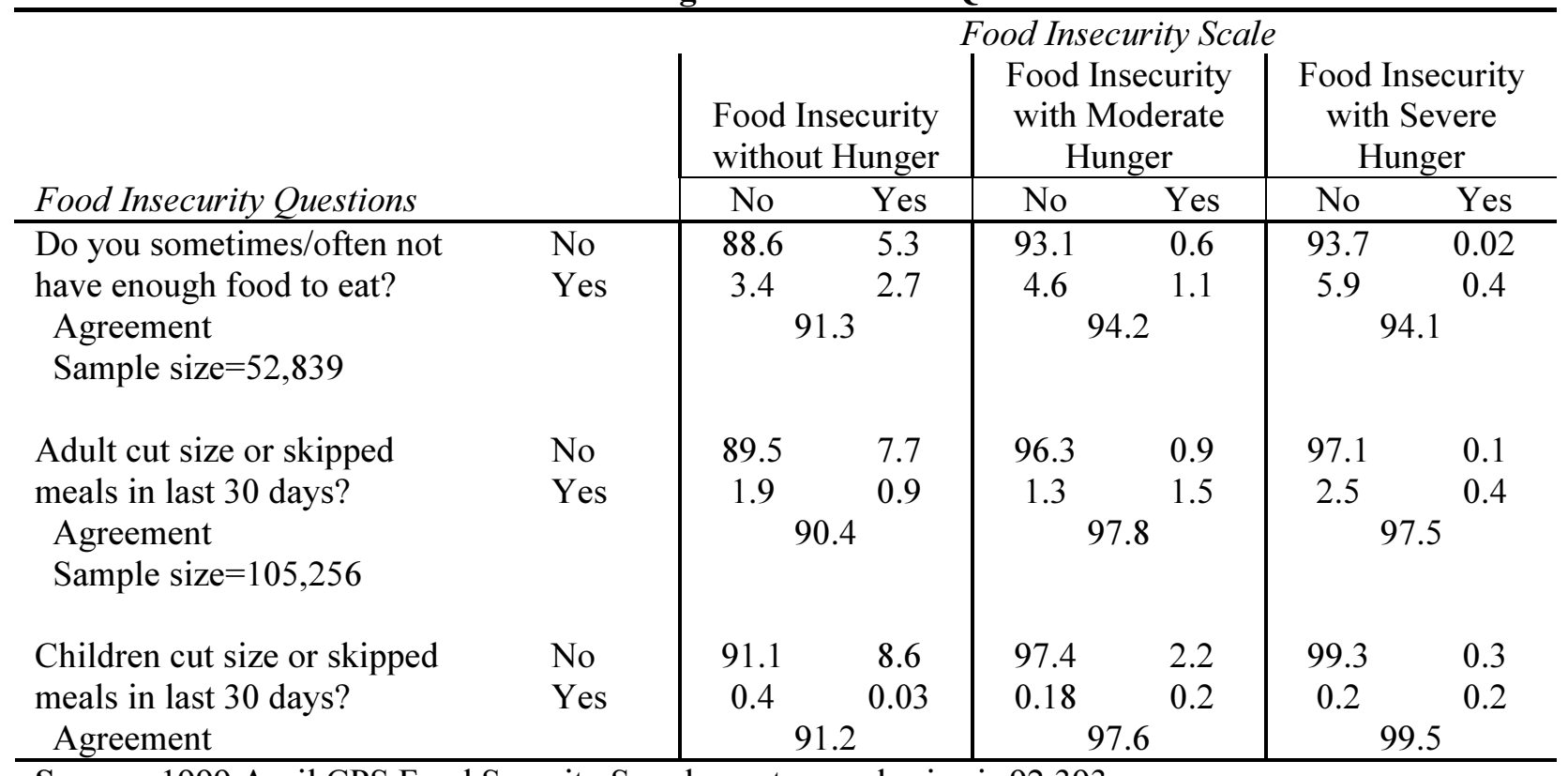

Source: 1999 April CPS Food Security Supplement; sample size is 92,393.

Notes: These tabulations are weighted. For each question, we only include the CPS households that were asked the specific question, dropping the households that were instead asked the similar experimental questions. 
TABLE A3

Components of the HEI

\begin{tabular}{lll}
\hline Component & \multicolumn{1}{c}{ Criteria for Score of 0} & \multicolumn{1}{c}{ Criteria for Score of 10} \\
\hline 1. Grains & 0 servings & $6-11$ servings* \\
2. Vegetables & 0 servings & $3-5$ servings \\
3. Fruits & 0 servings & $2-4$ servings \\
4. Milk & 0 servings & $2-3$ servings \\
5. Meat & 0 servings & $2-3$ servings \\
6. Total fat & $>44 \%$ calories from fat & $<31 \%$ calories from fat \\
7. Saturated fat & $>14 \%$ calories from s.f. & $<10 \%$ calories from s.f. \\
8. Cholesterol & $>449 \mathrm{mg}$ & $<300 \mathrm{mg}$ \\
9. Sodium & $>4,799 \mathrm{mg}$ & $<2,400 \mathrm{mg}$ \\
10. Variety & $<4$ different categories a day & $>7$ different categories a day \\
\hline
\end{tabular}

Note: This table is taken from the NHANES III manual. People with consumption or intakes between the maximum and minimum ranges or amounts were assigned scores proportionately. 
TABLE A4

Laboratory Measures of Inadequacy

\begin{tabular}{lll}
\hline \multicolumn{1}{c}{ Lab. Measure } & \multicolumn{1}{c}{ Ages/Gender } & \multicolumn{1}{c}{ Criteria for Inadequacy } \\
\hline Anemia & $0-11$ & hemoglobin $<11.5 \mathrm{~g} / \mathrm{dL}$ and hematocrit $<35 \%$. \\
& $12-17$ & hemoglobin $<12 \mathrm{~g} / \mathrm{dL}$ and hematocrit $<37 \%$. \\
& $>17 /$ Female & $\begin{array}{l}\text { hemoglobin }<12 \mathrm{~g} / \mathrm{dL} \text { and } \text { hematocrit }<36 \% . \\
\text { hemoglobin }<13 \mathrm{~g} / \mathrm{dL} \text { and hematocrit }<39 \% .\end{array}$ \\
& $>17 /$ Male & Serum cholesterol $>200 \mathrm{mg} / \mathrm{dL}$. \\
High blood cholesterol & & $\mathrm{BMI}<=5 \%$ tile $(\mathrm{gender} /$ age specific) \\
Low BMI & $0-20$ & $\mathrm{BMI}=<18.5$ \\
& $21-$ & $\mathrm{BMI}>=95 \% \mathrm{tile}$ (gender/age specific) \\
Obesity & $0-20$ & $\mathrm{BMI}>=30$ \\
& $21-$ & $<11.4 \mathrm{mmol} / \mathrm{L}$ \\
Short vitamin C & & $<1.05 \mu \mathrm{mol} / \mathrm{L}$ \\
Short vitamin A & $0-11$ & $<0.7 \mu \mathrm{mol} / \mathrm{L}$ \\
& $>11$ & $<11.6 \mu \mathrm{mol} / \mathrm{L}$ \\
Short vitamin E & & $<7 \mathrm{nmol} / \mathrm{L}$ \\
Short folate & &
\end{tabular}

Note: All values were taken from Wilson et al. (1991), except for low BMI and obesity, which were taken from the CDC. 


\section{References}

Andrews, Margaret, Mark Nord, Gary Bickel, and Steven Carlson. 2000. Household Food Security in the United States, 1999. Washington, DC: Economic Research Service/USDA.

Baugher, Eleanor, and Leatha Lamison-White. 1996. Poverty in the United States: 1995 (U.S. Bureau of the Census, Current Population Reports, Series P60-194). Washington, DC: U.S. Government Print Office.

Bickel, Gary, Mark Nord, Cristofer Price, William Hamilton, and John Cook. 2000. Guide to Measuring Household Food Security, Revised 2000. Alexandria, VA: U.S. Department of Agriculture, Food and Nutrition Service.

Citro, Constance, and Robert Michael, eds. 1995. Measuring Poverty. Washington, DC: National Academy Press.

Derrickson, Joda, Jennifer Anderson, and Anne Fisher. 2000. "Concurrent Validity of the Face Valid Food Security Measure.” Discussion Paper no. 1206-00, Institute for Research on Poverty, University of Wisconsin-Madison.

Hamilton, William, John Cook, William Thompson, Lawrence Buron, Edward Frongillo, Christine Olson, and Cheryl Wehler. 1997. Household Food Security in the United States in 1995: Technical Report of the Food Security Measurement Project. Alexandria, VA: United States Department of Agriculture, Food and Consumer Service, Office of Analysis and Evaluation.

Kennedy, Eileen, James Ohls, Steven Carlson, and Kathryn Fleming. 1995. "The Healthy Eating Index: Design and Applications." Journal of the American Dietetic Association 95 (10): 1103-1108.

Orshansky, Mollie. 1965. "Counting the poor: another look at the poverty profile. Social Security Bulletin, 28(1), 3-29.

Rose, Donald. 1999. "Economic Determinants and Dietary Consequences of Food Insecurity in the United States." The Journal of Nutrition, 129, 517S-520S.

Rose, Donald and Victor Oliveria. 1997. "Nutrient Intakes of Individuals from Food-Insufficient Households in the United States." American Journal of Public Health, 87(12), 1956-61.

Wilson, J.D., E. Braunwald, K. J. Isselbacher, R. G. Petersdorf, J. B. Martin, A. S. Fauci, R. K. Root, eds. 1991. Harrison's Principles of Internal Medicine. New York: McGraw-Hill. 
TABLE 1

Food Insecurity, Consumption, Clinical Outcome Measures

\begin{tabular}{|c|c|c|}
\hline Measure & Question & Notes \\
\hline \multicolumn{3}{|c|}{ Food Insecurity and Poverty Measures } \\
\hline - FSfam 1 & $\begin{array}{l}\text { - Family respondent reports there is } \\
\text { not enough food sometimes or often }\end{array}$ & \\
\hline - FSfam2 & $\begin{array}{l}\text { - Family respondent reports adults } \\
\text { skipped meals }\end{array}$ & - Not available for half of the sample \\
\hline - FSfam3 & $\begin{array}{l}\text { - Family respondent reports children } \\
\text { skipped meals }\end{array}$ & - Not available for half of the sample \\
\hline - FSself1 & - Self-report of skipping any meals & - Disregarded for children under 12 \\
\hline - FSself2 & $\begin{array}{l}\text { - Self-report of skipping meals at least } \\
4 \text { times in last } 30 \text { days. }\end{array}$ & - Disregarded for children under 12 \\
\hline - Poverty & $\begin{array}{l}\text { Poverty indicator based on U.S. } \\
\text { poverty definition }\end{array}$ & \\
\hline \multicolumn{3}{|c|}{ Consumption Measures } \\
\hline • HEI & - Healthy Eating Index (HEI) & - Not available for children under 2 \\
\hline - Calories & - Caloric intake last 24 hours & - Not available for children under 2 \\
\hline \multicolumn{3}{|c|}{ Clinical Measures } \\
\hline - Low BMI & $\begin{array}{l}\text { - Based on age/gender cut-offs for } \\
\text { BMI }\end{array}$ & \\
\hline - Obesity & $\begin{array}{l}\text { - Based on age/gender cut-offs for } \\
\text { BMI }\end{array}$ & \\
\hline - ShortACEF & $\begin{array}{l}\text { - Short vitamins A, C, E, or Folate, as } \\
\text { available }\end{array}$ & - See notes below \\
\hline - ShortA & - Short vitamin A & - Not available for children under 3 \\
\hline - ShortC & - Short vitamin C & - Not available for children under 5 \\
\hline - ShortE & - Short vitamin E & $\begin{array}{l}\text { - Not available for children under } 3 \\
\text { and disregarded for adults over } 11\end{array}$ \\
\hline - ShortFol & - Short folate & \\
\hline - Anemic & $\begin{array}{l}\text { - Anemic, based on hemoglobin and } \\
\text { hematocrit levels }\end{array}$ & - Not available for children under 4 \\
\hline - Hchol & $\begin{array}{l}\text { - High cholesterol based on serum } \\
\text { levels }\end{array}$ & - Not available for children under 4 \\
\hline
\end{tabular}

Note: See Tables 2A and 2B for sample sizes and means. 
TABLE 2A

Sample Size and Means for Primary Variables by Age Group

\begin{tabular}{|c|c|c|c|c|c|c|}
\hline \multirow[b]{2}{*}{ Variable } & \multicolumn{2}{|c|}{$0-5$} & \multicolumn{2}{|c|}{$6-11$} & \multicolumn{2}{|c|}{$12-17$} \\
\hline & $\mathrm{N}$ & Mean & $\mathrm{N}$ & Mean & $\mathrm{N}$ & Mean \\
\hline Full sample size & 7,008 & & 4,720 & & 2,648 & \\
\hline FSfam 1 & 6,984 & 0.068 & 4,704 & 0.058 & 2,638 & 0.063 \\
\hline FSfam2 & 3,251 & 0.109 & 2,121 & 0.077 & 1,427 & 0.102 \\
\hline FSfam3 & 3,247 & 0.037 & 2,119 & 0.024 & 1,366 & 0.030 \\
\hline FSself1 & - & - & - & - & 2,286 & 0.043 \\
\hline FSself2 & - & - & - & - & 2,283 & 0.022 \\
\hline Poverty & 6,354 & 0.279 & 4,320 & 0.255 & 2,393 & 0.222 \\
\hline HEI & 4,116 & 69.9 & 3,134 & 65.0 & 2,409 & 60.1 \\
\hline Calories & 5,859 & 1445 & 4,146 & 1901 & 2,411 & 2379 \\
\hline Obesity & 5,669 & 0.062 & 4,720 & 0.130 & 2,648 & 0.118 \\
\hline Low BMI & 5,669 & 0.063 & 4,720 & 0.037 & 2,648 & 0.021 \\
\hline ShortACEF & 1,743 & 0.247 & 2,889 & 0.147 & 2,285 & 0.169 \\
\hline ShortA & 1,592 & 0.264 & 2,805 & 0.118 & 2,248 & 0.000 \\
\hline ShortC & - & - & 2,635 & 0.017 & 2,170 & 0.062 \\
\hline ShortE & 1,592 & 0.011 & 2,805 & 0.009 & - & - \\
\hline ShortFol & 1,742 & 0.003 & 2,885 & 0.016 & 2,284 & 0.137 \\
\hline Anemic & 4,407 & 0.149 & 2,891 & 0.023 & 2,279 & 0.042 \\
\hline Hchol & 1,707 & 0.075 & 2,855 & 0.114 & 2,267 & 0.093 \\
\hline Age & 7,008 & 3.0 & 4,720 & 8.5 & 2,648 & 14.5 \\
\hline Male & 7,008 & 0.510 & 4,720 & 0.514 & 2,648 & 0.515 \\
\hline White & 7,008 & 0.633 & 4,720 & 0.660 & 2,648 & 0.660 \\
\hline Black & 7,008 & 0.161 & 4,720 & 0.156 & 2,648 & 0.153 \\
\hline Hispanic & 7,008 & 0.159 & 4,720 & 0.142 & 2,648 & 0.138 \\
\hline Urban & 7,008 & 0.490 & 4,720 & 0.483 & 2,648 & 0.467 \\
\hline Northeast & 7,008 & 0.178 & 4,720 & 0.185 & 2,648 & 0.196 \\
\hline Midwest & 7,008 & 0.237 & 4,720 & 0.228 & 2,648 & 0.229 \\
\hline South & 7,008 & 0.348 & 4,720 & 0.346 & 2,648 & 0.356 \\
\hline
\end{tabular}

Source: Authors' tabulations from NHANES III.

Notes: All means are weighted. See Table 1 for a description of the variable names. 
TABLE 2B

Sample Size and Means for Primary Variables by Age Group

\begin{tabular}{|c|c|c|c|c|c|c|}
\hline \multirow[b]{2}{*}{ Variable } & \multicolumn{2}{|c|}{ 18-64, without Children } & \multicolumn{2}{|c|}{ 18-64, with children } & \multicolumn{2}{|c|}{$65+$} \\
\hline & $\mathrm{N}$ & Mean & $\mathrm{N}$ & Mean & $\mathrm{N}$ & Mean \\
\hline Full sample size & 5,739 & & 8,627 & & 5,252 & \\
\hline FSfam1 & 6,279 & 0.027 & 8,033 & 0.047 & 5,218 & 0.017 \\
\hline FSfam 2 & 2,855 & 0.047 & 4,358 & 0.071 & 2,465 & 0.032 \\
\hline FSfam 3 & - & - & 3,870 & 0.026 & - & - \\
\hline FSself1 & 5,354 & 0.028 & 7,211 & 0.030 & 3,655 & 0.009 \\
\hline FSself2 & 5,348 & 0.013 & 7,199 & 0.015 & 3,651 & 0.004 \\
\hline Poverty & 5,747 & 0.098 & 7,277 & 0.166 & 4,493 & 0.116 \\
\hline HEI & 5,454 & 63.5 & 7,350 & 61.7 & 3,885 & 68.7 \\
\hline Calories & 5,454 & 2279 & 7,350 & 2317 & 3,885 & 1687 \\
\hline Obesity & 6,302 & 0.213 & 8,064 & 0.223 & 5,252 & 0.222 \\
\hline Low BMI & 6,302 & 0.032 & 8,064 & 0.024 & 5,252 & 0.025 \\
\hline ShortACEF & 5,407 & 0.256 & 7,195 & 0.307 & 4,200 & 0.133 \\
\hline ShortA & 5,360 & 0.003 & 7,125 & 0.001 & 4,144 & 0.002 \\
\hline ShortC & 5,146 & 0.127 & 6,916 & 0.158 & 3,721 & 0.087 \\
\hline ShortE & - & - & - & - & - & - \\
\hline ShortFol & 5,405 & 0.188 & 7,191 & 0.232 & 4,198 & 0.077 \\
\hline Anemic & 5,397 & 0.046 & 7,198 & 0.062 & 4,198 & 0.089 \\
\hline Hchol & 5,385 & 0.489 & 7,168 & 0.434 & 4,179 & 0.686 \\
\hline Age & 6,302 & 40.5 & 8,064 & 35.5 & 5,252 & 73.6 \\
\hline Male & 6,302 & 0.516 & 8,064 & 0.457 & 5,252 & 0.426 \\
\hline White & 6,302 & 0.793 & 8,064 & 0.687 & 5,252 & 0.858 \\
\hline Black & 6,302 & 0.101 & 8,064 & 0.133 & 5,252 & 0.081 \\
\hline Hispanic & 6,302 & 0.074 & 8,064 & 0.133 & 5,252 & 0.044 \\
\hline Urban & 6,302 & 0.517 & 8,064 & 0.484 & 5,252 & 0.432 \\
\hline Northeast & 6,302 & 0.218 & 8,064 & 0.194 & 5,252 & 0.216 \\
\hline Midwest & 6,302 & 0.246 & 8,064 & 0.227 & 5,252 & 0.260 \\
\hline South & 6,302 & 0.346 & 8,064 & 0.351 & 5,252 & 0.306 \\
\hline
\end{tabular}

Source: Authors' tabulations from NHANES III.

Note: All means are weighted. See Table 1 for a description of the variable names. 
TABLE 3

Regression Results for the 0-5 Age Group

\begin{tabular}{|c|c|c|c|c|c|c|c|}
\hline \multirow[b]{2}{*}{ Dependent Variable } & \multirow{2}{*}{$\begin{array}{c}\text { Dependent } \\
\text { Variable Mean }\end{array}$} & \multicolumn{6}{|c|}{ Independent Variables (OLS Coefficients with Std. Errors in Parentheses) } \\
\hline & & Poverty & FSfam 1 & $\mathrm{FSfam}^{\mathrm{a}}$ & $\mathrm{FSfam}^{\mathrm{a}}$ & FSself1 & FSself2 \\
\hline HEI & 69.9 & $\begin{array}{l}-1.51 * * \\
(0.482)\end{array}$ & $\begin{array}{c}0.698 \\
(0.780)\end{array}$ & $\begin{array}{c}0.559 \\
(0.951)\end{array}$ & $\begin{array}{l}-3.48 * * \\
(1.60)\end{array}$ & $\begin{array}{l}- \\
-\end{array}$ & $\begin{array}{l}- \\
- \\
\end{array}$ \\
\hline Calories & 1445 & $\begin{array}{l}60.5 * * \\
(17.3) \\
\end{array}$ & $\begin{array}{r}51.3 * \\
(27.6) \\
\end{array}$ & $\begin{array}{c}36.1 \\
(33.4) \\
\end{array}$ & $\begin{array}{l}-45.7 \\
(57.0) \\
\end{array}$ & $\begin{array}{l}- \\
-\end{array}$ & $\begin{array}{l}- \\
-\end{array}$ \\
\hline Obese & 0.062 & $\begin{array}{l}0.025 * * \\
(0.008)\end{array}$ & $\begin{array}{c}0.000 \\
(0.013)\end{array}$ & $\begin{array}{l}-0.006 \\
(0.015)\end{array}$ & $\begin{array}{l}-0.021 \\
(0.025)\end{array}$ & $\begin{array}{l}- \\
-\end{array}$ & $\begin{array}{l}- \\
-\end{array}$ \\
\hline Low BMI & 0.063 & $\begin{array}{l}-0.019 * * \\
(0.008)\end{array}$ & $\begin{array}{c}0.008 \\
(0.013) \\
\end{array}$ & $\begin{array}{c}0.031 * \\
(0.016) \\
\end{array}$ & $\begin{array}{l}0.091 * * \\
(0.026)\end{array}$ & $\begin{array}{l}- \\
-\end{array}$ & $\begin{array}{l}- \\
-\end{array}$ \\
\hline ShortACEF & 0.247 & $\begin{array}{l}0.059 * * \\
(0.025)\end{array}$ & $\begin{array}{c}0.066 \\
(0.040) \\
\end{array}$ & $\begin{array}{c}0.036 \\
(0.044) \\
\end{array}$ & $\begin{array}{l}-0.042 \\
(0.062)\end{array}$ & $\begin{array}{l}- \\
-\end{array}$ & $\begin{array}{l}- \\
-\end{array}$ \\
\hline ShortA & 0.264 & $\begin{array}{l}0.059 * * \\
(0.027)\end{array}$ & $\begin{array}{c}0.067 \\
(0.042) \\
\end{array}$ & $\begin{array}{c}0.037 \\
(0.045) \\
\end{array}$ & $\begin{array}{l}-0.046 \\
(0.064)\end{array}$ & $\begin{array}{l}- \\
-\end{array}$ & $\begin{array}{l}- \\
-\end{array}$ \\
\hline ShortC & - & $\begin{array}{l}- \\
-\end{array}$ & $\begin{array}{l}- \\
-\end{array}$ & $\begin{array}{l}- \\
- \\
-\end{array}$ & $\begin{array}{l}- \\
-\end{array}$ & $\begin{array}{l}- \\
-\end{array}$ & $\begin{array}{l}- \\
-\end{array}$ \\
\hline ShortE & 0.011 & $\begin{array}{c}0.006 \\
(0.006) \\
\end{array}$ & $\begin{array}{l}-0.001 \\
(0.010)\end{array}$ & $\begin{array}{c}0.007 \\
(0.010) \\
\end{array}$ & $\begin{array}{c}0.003 \\
(0.014) \\
\end{array}$ & $\begin{array}{l}- \\
-\end{array}$ & $\begin{array}{l}- \\
- \\
\end{array}$ \\
\hline ShortFol & 0.003 & $\begin{array}{c}0.005 \\
(0.003) \\
\end{array}$ & $\begin{array}{c}0.007 \\
(0.005) \\
\end{array}$ & $\begin{array}{c}0.000 \\
(0.004) \\
\end{array}$ & $\begin{array}{l}-0.002 \\
(0.006)\end{array}$ & $\begin{array}{l}- \\
-\end{array}$ & $\begin{array}{l}- \\
-\end{array}$ \\
\hline Anemic & 0.149 & $\begin{array}{l}0.045^{* *} \\
(0.013)\end{array}$ & $\begin{array}{l}-0.014 \\
(0.020) \\
\end{array}$ & $\begin{array}{l}0.044 * * \\
(0.022)\end{array}$ & $\begin{array}{c}0.015 \\
(0.035) \\
\end{array}$ & - & - \\
\hline Hchol & 0.075 & $\begin{array}{l}-0.013 \\
(0.016) \\
\end{array}$ & $\begin{array}{l}-0.035 \\
(0.025) \\
\end{array}$ & $\begin{array}{c}0.032 \\
(0.028) \\
\end{array}$ & $\begin{array}{c}0.030 \\
(0.039) \\
\end{array}$ & $\begin{array}{l}- \\
-\end{array}$ & $\begin{array}{l}- \\
-\end{array}$ \\
\hline
\end{tabular}

Notes: Each cell (coefficient/standard error combination) represents the result from a separate regression, where the dependent variable is listed in the first column and the particular independent variable is given as a column heading. All regressions include age, race dummies, a male dummy, and region*urban dummies. There are 7,008 individuals in NHANES III in this age group; the sample size for any particular regression, however, will depend on item response for the particular variables of interest. All means and regressions are weighted.

$*$ denotes significance at the 0.10 level; ** denotes significance at the 0.05 level.

${ }^{a}$ The questions underlying FSfam 2 and FSfam 3 were only asked on two of the four versions of the questionnaire, implying that about half of the respondents answered the questions. 
TABLE 4

Regression Results for the 6-11 Age Group

\begin{tabular}{|c|c|c|c|c|c|c|c|}
\hline \multirow[b]{2}{*}{ Dependent Variable } & \multirow{2}{*}{$\begin{array}{c}\text { Dependent } \\
\text { Variable Mean }\end{array}$} & \multicolumn{6}{|c|}{ Independent Variables (OLS Coefficients with Std. Errors in Parentheses) } \\
\hline & & Poverty & FSfam 1 & FSfam $2^{\mathrm{a}}$ & FSfam $^{\mathrm{a}}$ & FSself1 & FSself2 \\
\hline HEI & 65.0 & $\begin{array}{c}0.490 \\
(0.516)\end{array}$ & $\begin{array}{l}-0.005 \\
(0.898)\end{array}$ & $\begin{array}{l}-0.494 \\
(1.13)\end{array}$ & $\begin{array}{r}0.045 \\
(2.01)\end{array}$ & $\begin{array}{l}- \\
-\end{array}$ & $\begin{array}{l}- \\
-\end{array}$ \\
\hline Calories & 1901 & $\begin{array}{r}6.36 \\
(28.6) \\
\end{array}$ & $\begin{array}{c}90.6^{*} \\
(48.8)\end{array}$ & $\begin{array}{l}106.9 \\
(65.6)\end{array}$ & $\begin{array}{c}-10.8 \\
(117.6)\end{array}$ & - & - \\
\hline Obese & 0.130 & $\begin{array}{c}0.000 \\
(0.013)\end{array}$ & $\begin{array}{l}-0.011 \\
(0.022)\end{array}$ & $\begin{array}{l}-0.009 \\
(0.030)\end{array}$ & $\begin{array}{c}0.017 \\
(0.053)\end{array}$ & $\begin{array}{l}- \\
-\end{array}$ & $\begin{array}{l}- \\
-\end{array}$ \\
\hline Low BMI & 0.037 & $\begin{array}{l}-0.013 * \\
(0.007)\end{array}$ & $\begin{array}{l}-0.009 \\
(0.012)\end{array}$ & $\begin{array}{l}-0.030 * * \\
(0.015)\end{array}$ & $\begin{array}{l}-0.018 \\
(0.026)\end{array}$ & - & $\begin{array}{l}- \\
-\end{array}$ \\
\hline ShortACEF & 0.147 & $\begin{array}{c}0.023 \\
(0.017) \\
\end{array}$ & $\begin{array}{l}-0.004 \\
(0.028)\end{array}$ & $\begin{array}{c}0.031 \\
(0.034)\end{array}$ & $\begin{array}{l}0.119 * * \\
(0.060)\end{array}$ & - & - \\
\hline ShortA & 0.118 & $\begin{array}{l}0.030 * * \\
(0.015)\end{array}$ & $\begin{array}{c}0.005 \\
(0.026)\end{array}$ & $\begin{array}{c}0.035 \\
(0.032)\end{array}$ & $\begin{array}{c}0.101^{*} \\
(0.056)\end{array}$ & - & - \\
\hline ShortC & 0.017 & $\begin{array}{l}0.010 * \\
(0.006)\end{array}$ & $\begin{array}{l}-0.013 \\
(0.011)\end{array}$ & $\begin{array}{l}-0.008 \\
(0.012)\end{array}$ & $\begin{array}{l}-0.009 \\
(0.021)\end{array}$ & - & - \\
\hline ShortE & 0.009 & $\begin{array}{l}-0.002 \\
(0.005)\end{array}$ & $\begin{array}{l}-0.003 \\
(0.008)\end{array}$ & $\begin{array}{l}-0.007 \\
(0.009)\end{array}$ & $\begin{array}{l}-0.005 \\
(0.017)\end{array}$ & $\begin{array}{l}- \\
-\end{array}$ & $\begin{array}{l}- \\
-\end{array}$ \\
\hline ShortFol & 0.016 & $\begin{array}{l}-0.008 \\
(0.006)\end{array}$ & $\begin{array}{c}0.001 \\
(0.010)\end{array}$ & $\begin{array}{c}0.003 \\
(0.009)\end{array}$ & $\begin{array}{c}0.023 \\
(0.015)\end{array}$ & - & - \\
\hline Anemic & 0.023 & $\begin{array}{c}0.004 \\
(0.007)\end{array}$ & $\begin{array}{l}-0.023^{*} \\
(0.012)\end{array}$ & $\begin{array}{l}-0.005 \\
(0.013)\end{array}$ & $\begin{array}{l}-0.001 \\
(0.023)\end{array}$ & $\begin{array}{l}- \\
-\end{array}$ & $\begin{array}{l}- \\
-\end{array}$ \\
\hline Hchol & 0.114 & $\begin{array}{l}-0.008 \\
(0.015)\end{array}$ & $\begin{array}{l}-0.012 \\
(0.025)\end{array}$ & $\begin{array}{c}0.005 \\
(0.031)\end{array}$ & $\begin{array}{l}-0.021 \\
(0.056)\end{array}$ & $\begin{array}{l}- \\
-\end{array}$ & $\begin{array}{l}- \\
-\end{array}$ \\
\hline
\end{tabular}

Notes: Each cell (coefficient/standard error combination) represents the result of a separate regression, where the dependent variable is listed in the first column and the particular independent variable is given as a column heading. All regressions include age, race dummies, a male dummy, and region*urban dummies. There are 4,720 individuals in NHANES III in this age group; the sample size for any particular regression, however, will depend on item response for the particular variables of interest. All means and regressions are weighted. $*$ denotes significance at the 0.10 level; ** denotes significance at the 0.05 level.

${ }^{a}$ The questions underlying FSfam 2 and FSfam 3 were only asked on two of the 4 versions of the questionnaire, implying that about half of the respondents answered the questions. 
TABLE 5

Regression Results for the 12-17 Age Group

\begin{tabular}{|c|c|c|c|c|c|c|c|}
\hline \multirow[b]{2}{*}{ Dependent Variable } & \multirow{2}{*}{$\begin{array}{c}\text { Dependent } \\
\text { Variable Mean } \\
\end{array}$} & \multicolumn{6}{|c|}{ Independent Variables (OLS Coefficients with Std. Errors in Parentheses) } \\
\hline & & Poverty & FSfam 1 & FSfam $^{\mathrm{a}}$ & FSfam $^{\mathrm{a}}$ & FSself1 & FSself2 \\
\hline HEI & 60.1 & $\begin{array}{l}-0.758 \\
(0.604)\end{array}$ & $\begin{array}{l}-2.75 * * \\
(0.924)\end{array}$ & $\begin{array}{c}1.57 \\
(1.01)\end{array}$ & $\begin{array}{l}-1.75 \\
(1.83)\end{array}$ & $\begin{array}{l}-2.42 * * \\
(1.13)\end{array}$ & $\begin{array}{l}-1.49 \\
(1.57)\end{array}$ \\
\hline Calories & 2379 & $\begin{array}{l}-38.7 \\
(60.2) \\
\end{array}$ & $\begin{array}{c}-221.0 * * \\
(91.3)\end{array}$ & $\begin{array}{l}-188.2 * \\
(103.9)\end{array}$ & $\begin{array}{l}-408.1 * * \\
(188.5)\end{array}$ & $\begin{array}{l}550.8 * * \\
(112.8) \\
\end{array}$ & $\begin{array}{l}820.9 * * \\
(156.4)\end{array}$ \\
\hline Obese & 0.118 & $\begin{array}{l}0.050 * * \\
(0.017)\end{array}$ & $\begin{array}{c}0.030 \\
(0.027)\end{array}$ & $\begin{array}{c}0.002 \\
(0.030)\end{array}$ & $\begin{array}{l}-0.045 \\
(0.055)\end{array}$ & $\begin{array}{c}0.045 \\
(0.033)\end{array}$ & $\begin{array}{l}-0.080 * \\
(0.046)\end{array}$ \\
\hline Low BMI & 0.021 & $\begin{array}{c}0.006 \\
(0.008)\end{array}$ & $\begin{array}{l}-0.007 \\
(0.012)\end{array}$ & $\begin{array}{c}0.012 \\
(0.013)\end{array}$ & $\begin{array}{l}0.090 * * \\
(0.023)\end{array}$ & $\begin{array}{l}0.038^{* *} \\
(0.015)\end{array}$ & $\begin{array}{l}-0.008 \\
(0.020)\end{array}$ \\
\hline ShortACEF & 0.169 & $\begin{array}{c}0.007 \\
(0.020) \\
\end{array}$ & $\begin{array}{c}0.006 \\
(0.031) \\
\end{array}$ & $\begin{array}{l}-0.041 \\
(0.031)\end{array}$ & $\begin{array}{l}-0.052 \\
(0.055)\end{array}$ & $\begin{array}{c}0.015 \\
(0.038) \\
\end{array}$ & $\begin{array}{l}-0.031 \\
(0.052)\end{array}$ \\
\hline ShortA & 0.000 & $\begin{array}{c}0.001 \\
(0.001)\end{array}$ & $\begin{array}{l}-0.001 \\
(0.002)\end{array}$ & $\begin{array}{c}0.003 \\
(0.003)\end{array}$ & $\begin{array}{l}0.011^{* *} \\
(0.005)\end{array}$ & $\begin{array}{c}0.000 \\
(0.003)\end{array}$ & $\begin{array}{c}0.000 \\
(0.004)\end{array}$ \\
\hline ShortC & 0.062 & $\begin{array}{c}0.007 \\
(0.014)\end{array}$ & $\begin{array}{c}0.002 \\
(0.021)\end{array}$ & $\begin{array}{l}-0.027 \\
(0.020)\end{array}$ & $\begin{array}{c}0.005 \\
(0.038)\end{array}$ & $\begin{array}{c}0.025 \\
(0.027)\end{array}$ & $\begin{array}{c}0.023 \\
(0.038)\end{array}$ \\
\hline ShortE & - & - & - & - & - & - & - \\
\hline ShortFol & 0.137 & $\begin{array}{c}0.005 \\
(0.019)\end{array}$ & $\begin{array}{c}0.024 \\
(0.029)\end{array}$ & $\begin{array}{l}-0.031 \\
(0.028)\end{array}$ & $\begin{array}{l}-0.058 \\
(0.049)\end{array}$ & $\begin{array}{c}0.042 \\
(0.035)\end{array}$ & $\begin{array}{c}0.001 \\
(0.048)\end{array}$ \\
\hline Anemic & 0.042 & $\begin{array}{l}-0.004 \\
(0.011)\end{array}$ & $\begin{array}{c}0.018 \\
(0.017)\end{array}$ & $\begin{array}{c}0.022 \\
(0.015)\end{array}$ & $\begin{array}{l}0.090 * * \\
(0.026)\end{array}$ & $\begin{array}{c}0.004 \\
(0.020)\end{array}$ & $\begin{array}{l}-0.002 \\
(0.028)\end{array}$ \\
\hline Hchol & 0.093 & $\begin{array}{l}0.053 * * \\
(0.016)\end{array}$ & $\begin{array}{l}0.053^{* *} \\
(0.026)\end{array}$ & $\begin{array}{l}0.069^{* *} \\
(0.029)\end{array}$ & $\begin{array}{c}0.004 \\
(0.053)\end{array}$ & $\begin{array}{l}-0.045 \\
(0.031)\end{array}$ & $\begin{array}{l}-0.040 \\
(0.042)\end{array}$ \\
\hline
\end{tabular}

Notes: Each cell (coefficient/standard error combination) represents the result from a separate regression, where the dependent variable is listed in the first column and the particular independent variable is given as a column heading. All regressions include age, race dummies, a male dummy, and region*urban dummies. There are 2,648 individuals in NHANES III in this age group; the sample size for any particular regression, however, will depend on item response for the particular variables of interest. All means and regressions are weighted.

* denotes significance at the 0.10 level; ** denotes significance at the 0.05 level.

${ }^{a}$ The questions underlying FSfam 2 and FSfam 3 were only asked on two of the four versions of the questionnaire, implying that about half of the respondents answered the questions. 
TABLE 6

Regression Results for the 18-64 Age Group without Children

\begin{tabular}{|c|c|c|c|c|c|c|c|}
\hline \multirow[b]{2}{*}{ Dependent Variable } & \multirow[b]{2}{*}{$\begin{array}{c}\text { Dependent } \\
\text { Variable Mean }\end{array}$} & \multicolumn{6}{|c|}{ Independent Variables (OLS Coefficients with Std. Errors in Parentheses) } \\
\hline & & Poverty & FSfam 1 & $\mathrm{FSfam}^{\mathrm{a}}$ & $\mathrm{FSfam}^{\mathrm{a}}$ & FSself1 & FSself2 \\
\hline HEI & 63.5 & $\begin{array}{l}-4.00 * * \\
(0.620)\end{array}$ & $\begin{array}{l}-5.85 * * \\
(1.10)\end{array}$ & $\begin{array}{l}-3.88 * * \\
(1.20)\end{array}$ & $\begin{array}{l}- \\
-\end{array}$ & $\begin{array}{l}-3.00 * * \\
(1.07)\end{array}$ & $\begin{array}{l}-4.73 * * \\
(1.52)\end{array}$ \\
\hline Calories & 2284 & $\begin{array}{l}-85.5^{*} \\
(49.7) \\
\end{array}$ & $\begin{array}{r}54.5 \\
(87.8) \\
\end{array}$ & $\begin{array}{l}-91.8 \\
(99.2) \\
\end{array}$ & $\begin{array}{l}- \\
-\end{array}$ & $\begin{array}{l}270.1 * * \\
(85.3)\end{array}$ & $\begin{array}{l}416.8 * * \\
(121.4) \\
\end{array}$ \\
\hline Obese & 0.213 & $\begin{array}{l}0.046 * * \\
(0.019)\end{array}$ & $\begin{array}{l}0.069 * * \\
(0.033)\end{array}$ & $\begin{array}{l}-0.008 \\
(0.038)\end{array}$ & $\begin{array}{l}- \\
-\end{array}$ & $\begin{array}{l}0.082 * * \\
(0.033)\end{array}$ & $\begin{array}{c}0.155 * * \\
(0.048)\end{array}$ \\
\hline Low BMI & 0.032 & $\begin{array}{c}0.010 \\
(0.009)\end{array}$ & $\begin{array}{c}0.020 \\
(0.014)\end{array}$ & $\begin{array}{c}0.004 \\
(0.017)\end{array}$ & $\begin{array}{l}- \\
-\end{array}$ & $\begin{array}{l}0.032 * * \\
(0.014)\end{array}$ & $\begin{array}{c}0.012 \\
(0.021)\end{array}$ \\
\hline ShortACEF & 0.255 & $\begin{array}{l}0.078 * * \\
(0.021)\end{array}$ & $\begin{array}{l}0.205^{* *} \\
(0.036)\end{array}$ & $\begin{array}{l}0.112 * * \\
(0.039)\end{array}$ & $\begin{array}{l}- \\
-\end{array}$ & $\begin{array}{l}0.155 * * \\
(0.036)\end{array}$ & $\begin{array}{l}0.145 * * \\
(0.052)\end{array}$ \\
\hline ShortA & 0.003 & $\begin{array}{c}0.003 \\
(0.003)\end{array}$ & $\begin{array}{c}0.008 \\
(0.005)\end{array}$ & $\begin{array}{c}0.000 \\
(0.007)\end{array}$ & $\begin{array}{l}- \\
-\end{array}$ & $\begin{array}{c}0.003 \\
(0.004)\end{array}$ & $\begin{array}{c}0.001 \\
(0.006)\end{array}$ \\
\hline ShortC & 0.123 & $\begin{array}{l}0.099 * * \\
(0.017)\end{array}$ & $\begin{array}{l}0.179 * * \\
(0.029)\end{array}$ & $\begin{array}{l}0.089 * * \\
(0.031)\end{array}$ & $\begin{array}{l}- \\
-\end{array}$ & $\begin{array}{l}0.122 * * \\
(0.028)\end{array}$ & $\begin{array}{l}0.134 * * \\
(0.041)\end{array}$ \\
\hline ShortE & - & - & - & - & $\begin{array}{l}- \\
-\end{array}$ & - & - \\
\hline ShortFol & 0.187 & $\begin{array}{c}0.013 \\
(0.019)\end{array}$ & $\begin{array}{c}0.056^{*} \\
(0.033)\end{array}$ & $\begin{array}{l}0.091 * * \\
(0.034)\end{array}$ & $\begin{array}{l}- \\
-\end{array}$ & $\begin{array}{c}0.037 \\
(0.033)\end{array}$ & $\begin{array}{c}0.017 \\
(0.047)\end{array}$ \\
\hline Anemic & 0.045 & $\begin{array}{c}0.004 \\
(0.011)\end{array}$ & $\begin{array}{l}-0.027 \\
(0.018)\end{array}$ & $\begin{array}{l}0.055^{* *} \\
(0.017)\end{array}$ & $\begin{array}{l}- \\
-\end{array}$ & $\begin{array}{c}0.033^{*} \\
(0.018)\end{array}$ & $\begin{array}{l}0.069 * * \\
(0.026)\end{array}$ \\
\hline Hchol & 0.482 & $\begin{array}{l}-0.010 \\
(0.023)\end{array}$ & $\begin{array}{c}0.024 \\
(0.038)\end{array}$ & $\begin{array}{l}-0.012 \\
(0.044)\end{array}$ & $\begin{array}{l}- \\
-\end{array}$ & $\begin{array}{l}-0.010 \\
(0.038)\end{array}$ & $\begin{array}{l}-0.008 \\
(0.055)\end{array}$ \\
\hline
\end{tabular}

Notes: Each cell (coefficient/standard error combination) represents the result from a separate regression, where the dependent variable is listed in the first column and the particular independent variable is given as acolumn heading. All regressions include age, race dummies, a male dummy, and region*urban dummies. There are 5,739 individuals in NHANES III in this age group; the sample size for any particular regression, however, will depend on item response for the particular variables of interest. All means and regressions are weighted.

$*$ denotes significance at the 0.10 level; ** denotes significance at the 0.05 level.

${ }^{a}$ The questions underlying FSfam 2 and FSfam 3 were only asked on two of the four versions of the questionnaire, implying that about half of the respondents answered the questions. 
TABLE 7

Regression Results for the 18-64 Age Group with Children

\begin{tabular}{|c|c|c|c|c|c|c|c|}
\hline \multirow[b]{2}{*}{ Dependent Variable } & \multirow[b]{2}{*}{$\begin{array}{c}\text { Dependent } \\
\text { Variable Mean }\end{array}$} & \multicolumn{6}{|c|}{ Independent Variables (OLS Coefficients with Std. Errors in Parentheses) } \\
\hline & & Poverty & FSfam 1 & $\mathrm{FSfam}^{\mathrm{a}}$ & 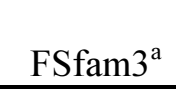 & FSself1 & FSself2 \\
\hline HEI & 61.8 & $\begin{array}{l}-2.03 * * \\
(0.418)\end{array}$ & $\begin{array}{l}-2.27 * * \\
(0.660)\end{array}$ & $\begin{array}{l}-0.292 \\
(0.741)\end{array}$ & $\begin{array}{l}-4.54 * * \\
(1.247)\end{array}$ & $\begin{array}{l}-1.90 * * \\
(0.828)\end{array}$ & $\begin{array}{l}-2.65 * * \\
(1.158)\end{array}$ \\
\hline Calories & 2311 & $\begin{array}{l}-0.145 \\
(33.5)\end{array}$ & $\begin{array}{l}-64.7 \\
(52.8)\end{array}$ & $\begin{array}{c}82.4 \\
(58.3) \\
\end{array}$ & $\begin{array}{l}-85.9 \\
(99.9)\end{array}$ & $\begin{array}{l}-82.2 \\
(65.8)\end{array}$ & $\begin{array}{c}-146.8 \\
(92.1)\end{array}$ \\
\hline Obese & 0.223 & $\begin{array}{l}0.047 * * \\
(0.014)\end{array}$ & $\begin{array}{c}0.012 \\
(0.023)\end{array}$ & $\begin{array}{c}0.010 \\
(0.026)\end{array}$ & $\begin{array}{l}-0.016 \\
(0.045)\end{array}$ & $\begin{array}{c}0.100 * * \\
(0.029)\end{array}$ & $\begin{array}{l}0.113 * * \\
(0.04)\end{array}$ \\
\hline Low BMI & 0.024 & $\begin{array}{l}-0.005 \\
(0.005)\end{array}$ & $\begin{array}{l}0.017 * * \\
(0.008)\end{array}$ & $\begin{array}{c}0.010 \\
(0.009)\end{array}$ & $\begin{array}{c}0.009 \\
(0.015)\end{array}$ & $\begin{array}{c}0.006 \\
(0.011)\end{array}$ & $\begin{array}{l}0.029 * \\
(0.015)\end{array}$ \\
\hline ShortACEF & 0.306 & $\begin{array}{l}0.117 * * \\
(0.016)\end{array}$ & $\begin{array}{l}0.127 * * \\
(0.026)\end{array}$ & $\begin{array}{l}0.065 * * \\
(0.027)\end{array}$ & $\begin{array}{l}0.114 * * \\
(0.047)\end{array}$ & $\begin{array}{c}0.058^{*} \\
(0.032)\end{array}$ & $\begin{array}{l}0.165 * * \\
(0.045)\end{array}$ \\
\hline ShortA & 0.001 & $\begin{array}{l}0.002 * * \\
(0.001)\end{array}$ & $\begin{array}{c}0.002 \\
(0.002)\end{array}$ & $\begin{array}{c}0.002 \\
(0.002)\end{array}$ & $\begin{array}{c}0.001 \\
(0.003)\end{array}$ & $\begin{array}{c}0.002 \\
(0.002)\end{array}$ & $\begin{array}{c}0.002 \\
(0.003)\end{array}$ \\
\hline ShortC & 0.159 & $\begin{array}{l}0.098 * * \\
(0.013)\end{array}$ & $\begin{array}{l}0.122 * * \\
(0.021)\end{array}$ & $\begin{array}{l}0.067 * * \\
(0.022)\end{array}$ & $\begin{array}{l}0.140 * * \\
(0.037)\end{array}$ & $\begin{array}{l}0.052 * * \\
(0.026)\end{array}$ & $\begin{array}{l}0.133 * * \\
(0.036)\end{array}$ \\
\hline ShortE & - & - & - & - & - & - & - \\
\hline ShortFol & 0.231 & $\begin{array}{l}0.070 * * \\
(0.015)\end{array}$ & $\begin{array}{l}0.068 * * \\
(0.024)\end{array}$ & $\begin{array}{c}0.020 \\
(0.025)\end{array}$ & $\begin{array}{l}-0.022 \\
(0.043)\end{array}$ & $\begin{array}{l}0.076^{* *} \\
(0.03)\end{array}$ & $\begin{array}{l}0.175^{*} * \\
(0.041)\end{array}$ \\
\hline Anemic & 0.062 & $\begin{array}{l}-0.003 \\
(0.008)\end{array}$ & $\begin{array}{c}0.012 \\
(0.014)\end{array}$ & $\begin{array}{l}-0.018 \\
(0.014)\end{array}$ & $\begin{array}{c}0.015 \\
(0.024)\end{array}$ & $\begin{array}{l}-0.022 \\
(0.017)\end{array}$ & $\begin{array}{l}-0.029 \\
(0.023)\end{array}$ \\
\hline Hchol & 0.443 & $\begin{array}{c}0.004 \\
(0.017)\end{array}$ & $\begin{array}{c}0.015 \\
(0.027)\end{array}$ & $\begin{array}{l}-0.014 \\
(0.030)\end{array}$ & $\begin{array}{c}0.018 \\
(0.052)\end{array}$ & $\begin{array}{c}0.034 \\
(0.034)\end{array}$ & $\begin{array}{l}0.111 * * \\
(0.047)\end{array}$ \\
\hline
\end{tabular}

Notes: Each cell (coefficient/standard error combination) represents the result from a separate regression, where the dependent variable is listed in the first column and the particular independent variable is given as a column heading. All regressions include age, race dummies, a male dummy, and region*urban dummies. There are 8,627 individuals in NHANES III in this age group; the sample size for any particular regression, however, will depend on item response for the particular variables of interest. All means and regressions are weighted.

* denotes significance at the 0.10 level; ** denotes significance at the 0.05 level.

${ }^{a}$ The questions underlying FSfam 2 and FSfam 3 were only asked on two of the four versions of the questionnaire, implying that about half of the respondents answered the questions 
TABLE 8

Regression Results for the 65+ Age Group

\begin{tabular}{|c|c|c|c|c|c|c|c|}
\hline \multirow[b]{2}{*}{ Dependent Variable } & \multirow{2}{*}{$\begin{array}{c}\text { Dependent } \\
\text { Variable Mean }\end{array}$} & \multicolumn{6}{|c|}{ Independent Variables (OLS Coefficients with Std. Errors in Parentheses) } \\
\hline & & Poverty & FSfam 1 & FSfam $2^{\circ}$ & $\mathrm{FSfam}^{\circ}$ & FSself1 & FSself2 \\
\hline HEI & 68.7 & $\begin{array}{l}-3.965^{* *} \\
(0.743)\end{array}$ & $\begin{array}{l}-5.945^{* *} \\
(1.70)\end{array}$ & $\begin{array}{l}-0.405 \\
(1.74)\end{array}$ & - & $\begin{array}{l}-8.906 * * \\
(2.32)\end{array}$ & $\begin{array}{l}-7.027 * * \\
(3.43)\end{array}$ \\
\hline Calories & 1687 & $\begin{array}{l}-112.717 * * \\
(38.0)\end{array}$ & $\begin{array}{l}-269.031 * * \\
(85.8)\end{array}$ & $\begin{array}{l}-166.459 * \\
(88.5)\end{array}$ & $\begin{array}{l}- \\
-\end{array}$ & $\begin{array}{l}-50.387 \\
(117.8)\end{array}$ & $\begin{array}{l}-28.994 \\
(173.9)\end{array}$ \\
\hline Obese & 0.222 & $\begin{array}{l}-0.002 \\
(0.023)\end{array}$ & $\begin{array}{c}0.064 \\
(0.050)\end{array}$ & $\begin{array}{c}0.033 \\
(0.055)\end{array}$ & - & $\begin{array}{l}-0.002 \\
(0.072)\end{array}$ & $\begin{array}{c}0.006 \\
(0.108)\end{array}$ \\
\hline Low BMI & 0.025 & $\begin{array}{l}0.024 * * \\
(0.009)\end{array}$ & $\begin{array}{l}0.066^{* *} \\
(0.019)\end{array}$ & $\begin{array}{c}0.023 \\
(0.020) \\
\end{array}$ & $\begin{array}{l}- \\
-\end{array}$ & $\begin{array}{l}0.104 * * \\
(0.027)\end{array}$ & $\begin{array}{l}0.261 * * \\
(0.040)\end{array}$ \\
\hline ShortACEF & 0.133 & $\begin{array}{l}0.084 * * \\
(0.019)\end{array}$ & $\begin{array}{l}0.148 * * \\
(0.041)\end{array}$ & $\begin{array}{c}0.036 \\
(0.042) \\
\end{array}$ & - & $\begin{array}{l}0.192 * * \\
(0.059)\end{array}$ & $\begin{array}{l}0.438 * * \\
(0.088)\end{array}$ \\
\hline ShortA & 0.002 & $\begin{array}{c}0.003 \\
(0.003)\end{array}$ & $\begin{array}{c}0.004 \\
(0.006)\end{array}$ & $\begin{array}{l}-0.002 \\
(0.007)\end{array}$ & - & $\begin{array}{l}-0.002 \\
(0.008)\end{array}$ & $\begin{array}{l}-0.002 \\
(0.012)\end{array}$ \\
\hline ShortC & 0.087 & $\begin{array}{l}0.072 * * \\
(0.016)\end{array}$ & $\begin{array}{l}0.159 * * \\
(0.035)\end{array}$ & $\begin{array}{l}0.075 * * \\
(0.035)\end{array}$ & - & $\begin{array}{l}0.201 * * \\
(0.049)\end{array}$ & $\begin{array}{l}0.488 * * \\
(0.073)\end{array}$ \\
\hline ShortE & - & - & - & - & - & - & - \\
\hline ShortFol & 0.077 & $\begin{array}{c}0.056^{* *} \\
(0.015)\end{array}$ & $\begin{array}{c}0.063 * \\
(0.033)\end{array}$ & $\begin{array}{c}0.060 * \\
(0.033)\end{array}$ & - & $\begin{array}{l}0.202 * * \\
(0.047)\end{array}$ & $\begin{array}{l}0.439 * * \\
(0.070)\end{array}$ \\
\hline Anemic & 0.089 & $\begin{array}{l}0.036^{* *} \\
(0.016)\end{array}$ & $\begin{array}{l}-0.033 \\
(0.035)\end{array}$ & $\begin{array}{c}0.023 \\
(0.037) \\
\end{array}$ & - & $\begin{array}{l}-0.03 \\
(0.048)\end{array}$ & $\begin{array}{l}-0.06 \\
(0.072)\end{array}$ \\
\hline Hchol & 0.686 & $\begin{array}{c}0.012 \\
(0.026)\end{array}$ & $\begin{array}{l}-0.009 \\
(0.056)\end{array}$ & $\begin{array}{c}0.021 \\
(0.062)\end{array}$ & - & $\begin{array}{l}-0.067 \\
(0.080)\end{array}$ & $\begin{array}{l}-0.257 * * \\
(0.120)\end{array}$ \\
\hline
\end{tabular}

Notes: Each cell (coefficient/standard error combination) represents the result from a separate regression, where the dependent variable is listed in the first column and the particular independent variable is given as acolumn heading. All regressions include age, race dummies, a male dummy, and region*urban dummies. There are 5,252 individuals in NHANES III in this age group; the sample size for any particular regression, however, will depend on item response for the particular variables of interest. All means and regressions are weighted.

*denotes significance at the 0.10 level; ** denotes significance at the 0.05 level.

${ }^{a}$ The questions underlying FSfam 2 and FSfam 3 were only asked on two of the four versions of the questionnaire, implying that about half of the respondents answered the questions. 